\title{
Using SW PRACTIS for education and training purposes for the integrated rescue system - the case study
}

\author{
Jakub Rak ${ }^{1 *}$, Petr Svoboda ${ }^{1}$, and Dusan Vicar $^{1}$ \\ ${ }^{1}$ Tomas Bata University in Zlín, nám. T. G. Masaryka 5555, 76001 Zlín, Czech Republic
}

\begin{abstract}
This article describes a case study of the SW application Practis being used for education and training purposes in the field of emergency management. The case study is focused on a traffic accident with a leakage of a dangerous chemical substance in the town of Kroměřǐz. The article further describes this event together with the procedure of creating a scenario for its solution and the subsequent evaluation of the training performed using the SW. The case study substantiates the importance of SW support for the education and preparation of members of the Integrated Rescue System; in addition, it enables education to be performed through play and practical training. Finally, the article discusses the possibilities and significance of SW Practis in the educational processes and the possibilities of interconnecting advantages of live and computer simulations.
\end{abstract}

\section{Introduction}

Training of specialists from the field of Integrated Rescue System (IRS) has a long tradition in the Czech Republic. Currently, there are two main approaches towards their preparation; it is the theoretical and practical training [1].

These approaches are interlinked and used cohesively. Both advantages and disadvantages of individual forms of training are discussed by a large number of authors [2]. A specific category in this field is the use of simulation, which is primarily connected with practical training. In particular, the use of simulation in the process of education and preparation of the IRS brings increased efficiency in acquiring new skills. As stated in professional literature, simulation has its irreplaceable position in these processes and it is used mainly for training [3]. Due to a large number of activities that IRS members have to manage and the need for their effective co-operation, it is essential to use functional methods and tools for their training and education. One of these tools is simulation [4]. The simulation completed by basic studies and training, which is focused on the prescribed topics, enables testing one's knowledge and developing it in an environment resembling reality. However, the form of simulation might pose a problem. Let us assume that the simulation of training can be live or computer-based [4]. It can also employ specialized SW tools to support and implement the training. This means that computer simulations are used and these may be supplemented with live simulation elements. One of these specialized SW tools is SW Practis. This SW serves to prepare and support training by means of both live and computer-based simulations.

\section{Problem formulation}

As claimed by literature [1], activities of the IRS can be divided into three groups: activities done prior to the occurrence of the emergency event (EE), those done during its course, and activities after the EE has ended. Each group of activities consists of sets of elements and tasks, which leads to the reduction of risk of the formation of the EEs, their consequences and effects. In the Czech Republic, the major elements of the protection system against the EE include IRS that means the fire rescue services, Police of the $\mathrm{CR}$, emergency medical service and others. Activities are defined as firefighting, rescue and recovery services, evacuation, decontamination, emergency supplying of drinking water, sheltering, protection against pyrotechnic, etc. This enumeration implies the necessity for the cooperation of members of these services and harmonization of their activities. Undoubtedly, such cooperation is a complex process, which depends on the type of the EE and its extent.

Cooperation of the IRS with other entities and the efficient performance of individual activities must be planned and prepared in advance. Based on a threat and risk analysis, it is possible to determine the optimal procedures for each individual solution to the EE. According to Anon 2007, these procedures have been extensively mapped out and there exists a number of methods and tools to implement them (e.g. model action activities of the IRS). However, the cooperation of individual departments of the services and their preparedness for various activities to prevent, reduce and eliminate any possible effects of the EE may be problematic. In particular, this applies to serious EEs 
that occur less frequently and therefore, services falling under the system of protection have less experience in managing them. Moreover, some specific EEs with a large period of occurrences in time can be problematic. This implies that effective training and education of the individual services and their mutual cooperation in the event of the EE should be a top priority. Naturally, the use of SW tools for support and implementation of training is important also for relatively common activities. In this case the simulation serves, in particular, for verifying knowledge and skills, and practicing them.

The IRS training supported by SW tools is a complex process that requires advance preparation. SW tools used in these training processes allow a reduction in the financial demands of the training. SW Practis is a tool that considerably simplifies the preparation of the training. Therefore, the way of applying this SW tool into the process of preparation and implementation of the IRS training must be developed.

\section{Materials and methods}

SW Practis was used to implement a case study. SW tool Pratis consists of three basic modules (see Fig. 1); each module contains subcategories that are used to control the entire tool. The main modules are training, scenarios, and a module for administration and setting of the SW. The Training module serves for the actual implementation of the training and its simulation. Based on the prescribed scenario, it enables the implementation of individual activities while maintaining their correct sequence. In addition, an important feature of the SW is the evaluation of the training; this feature enables the evaluation of the time that the tasks took to complete. The module Scenarios is intended for implementing, creating and setting the parameters of scenarios. Creating a scenario is a precondition for the subsequent performance of training. Furthermore, the module contains tabular and graphical depictions of the scenario. The module Administration is used for managing a database and users. It enables dividing the users into individual groups, managing their authorization and accounts.

The tool is controlled through the web interface that allows setting the language version either for English or Czech language. The advantage of this approach is the possibility to work within a common database that enables cooperation of multiple users from different locations.

\section{Problem solution}

The support for training of the IRS using SW Practis is explained by means of a case study in the conditions of the Czech Republic.

The case study "Traffic accident with a leakage of a dangerous chemical substance (DCS)," which uses SW Practis for the preparation and implementation of training.
The case study describes a way of using SW Practis during the implementation of training focused on a traffic accident with a leakage of DCS.

Fig. 1. SW Practis basic modules.

The process of using the SW can be divided into the following steps:

- Defining the EE to be simulated;

- Preparing a scenario for the given simulation;

- Training preparation;

- Training performance;

- Evaluation.

\subsection{Defining the EE to be simulated}

Based on the planned training scenario the traffic accident is taking place in the town of Kroměříž at a roundabout intersection of roads 367 and 432. Fig. 2 depicts the place of the accident and deployment of the main services of the IRS. There was a collision of a passenger vehicle that did not yield to a tank truck carrying a DCS at the roundabout. The damage to the tank caused a subsequent leakage of diesel oil. The area affected by the leakage of diesel oil is shown in Fig. 3 together with a model of this leakage

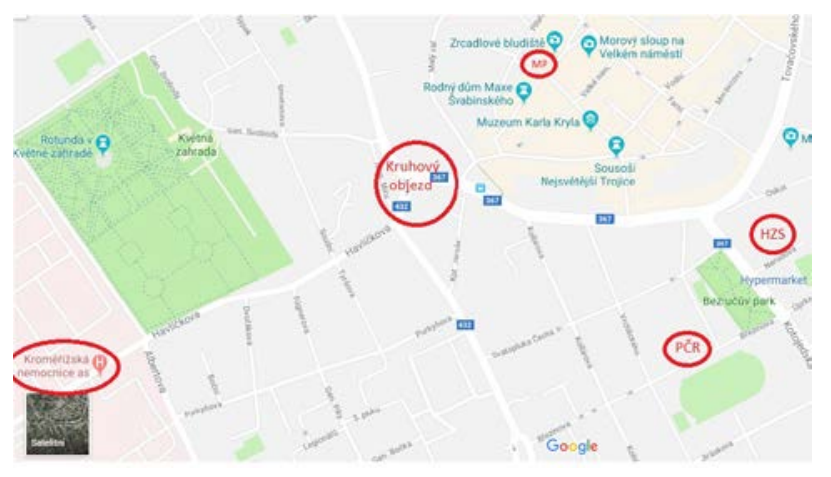

Fig. 2. Map of location of traffic accident [9].

\subsection{Preparing a scenario for the given simulation}

In order to perform the training, firstly a scenario of the EE had to be implemented. For this purpose, involved participants and individual services of the IRS were defined. These included: a driver of the passenger car (driver 1), a driver of the tank trunk (driver 2), a witness of the accident, members of the Municipal Police of Kroměříž, Czech Police officers, members of the Czech Fire Rescue Service, emergency medical service personnel, personnel of the Road and Motorway 
Directorate of the CR, and workers of a decontamination company.

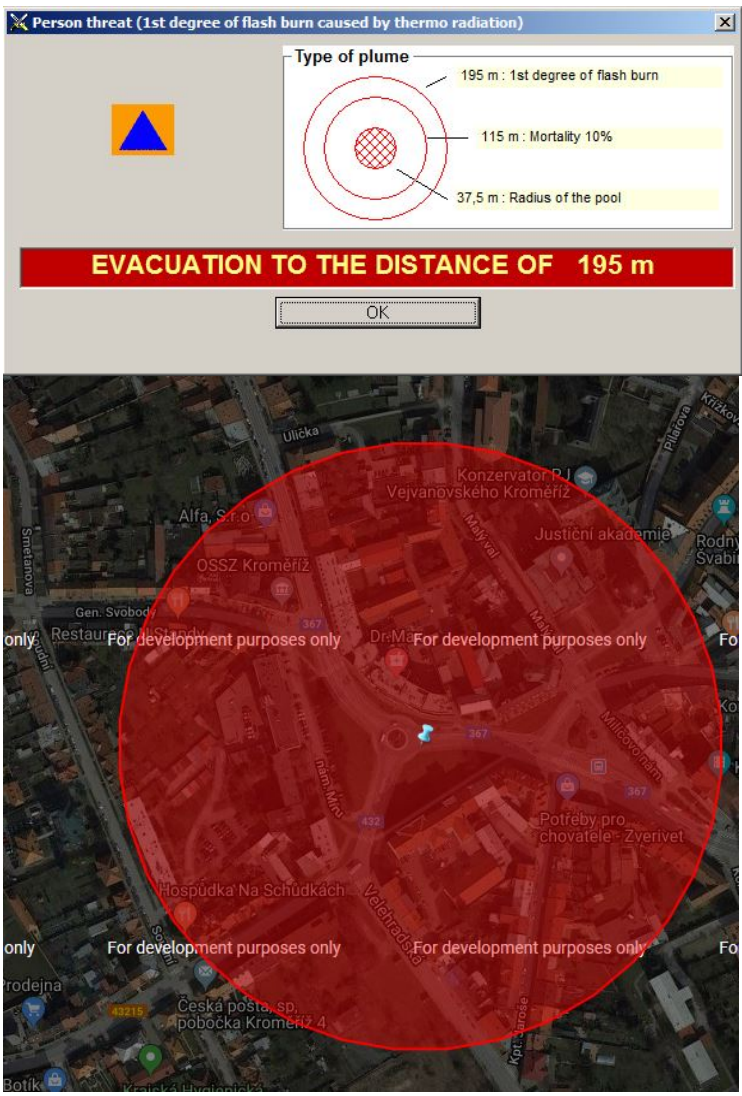

Fig. 3. Model of dangerous area of traffic accident $[8,9]$.

Activities for every entity involved in the prepared training scenario were specified. In addition, parameters necessary for performing the training were defined for every activity using SW Practis. These parameters are as follows:

- "Start" - the time of commencement of the activity;

- "Duration of the activity" - "Time" (real time of the activity);

- "Play time duration" - "Her. Time" (duration of the training);

- Assigning a participant to the activity.
Fig 4. The example of assigning parameters in SW Practis [7].

The difference between "duration" and "play time duration" is given by possible different time duration of the activity in the event of using the virtual simulation. The arrival to the place of the EE can serve as an example. This means that for the IRS the "duration" is 10 min. If the training has a form of live simulation, the "play time duration" is to be $10 \mathrm{~min}$ as well. In the event of the virtual form, the "play time duration" can be for instance 1 minute. The reason for this is reducing time during the training process that does not require the real performance of activities (the activity is performed only as a mental process, a virtual process in a PC, etc.). An example of assigning parameters is depicted in Fig. 4.

Upon assigning the basic parameters to all activities, the interconnections of these activities are defined. Fig. 5 shows the interconnections of individual activities (their sequence).

Fig 5. The example of interconnections of individual activities in SW Practis [7].

The preparation of the scenario is concluded by assigning individual entities to the user accounts so that every employee can simulate activities that correspond to his or her province. A part of the resulting scenario is depicted in Fig. 6.

Fig. 6. The part of the scenario in SW Practis [7].

\subsection{Training performance}

Once the scenario is finished, it is to be validated. SW Practis is responsible for searching possible infinite loops or non-completed activities. It is an automated scenario check. In the event of finding a problem, the SW provides guidance on its identification and removal.

After successful validation, the training is created. The training is based on the selected scenario. The 
created training must be assigned a basic parameter, which is the start date and time. Based on assignment of user accounts, the SW invites users by e-mail (if an email address has been provided) to perform the training within a given deadline.

The actual training is carried out by individual users independently and the entire process is controlled by a timeline of the scenario.

\subsection{Evaluation}

The final phase after the completion of the training is evaluation. Any discrepancy between the planned duration and the real duration of the training is evaluated.

The crucial activities, duration of which does not correspond to the duration of the actual performance of the training, are identified by means of the SW. These activities are listed in Tab. 1.

Table 1. The scenario activities.

\begin{tabular}{|c|c|c|c|}
\hline $\begin{array}{c}\text { Partici } \\
\text { pant }\end{array}$ & Activity & $\begin{array}{c}\text { Plann } \\
\text { ed Time }\end{array}$ & $\begin{array}{c}\text { Exercises } \\
\text { Time }\end{array}$ \\
\hline FRS & $\begin{array}{c}\text { Evaluatio } \\
\text { n of } \\
\text { information }\end{array}$ & 1 & $2-3$ \\
\hline FRS & Arrival & 1 & $5-6$ \\
\hline $\begin{array}{c}\text { Ambula } \\
\text { nce }\end{array}$ & Arrival & 1 & $4-5$ \\
\hline PCR & Arrival & 1 & $3-5$ \\
\hline FRS & $\begin{array}{c}\text { Arrival of } \\
\text { other units }\end{array}$ & 1 & $5-6$ \\
\hline $\begin{array}{c}\text { Deconta } \\
\text { mination } \\
\text { Firm }\end{array}$ & Arrival & 1 & $10-15$ \\
\hline MP & $\begin{array}{c}\text { Receiving } \\
\text { Information }\end{array}$ & 1 & $2-3$ \\
\hline
\end{tabular}

The training is repeated in 3 cycles and the individual results are shown in the table. Based on their comparison, it is possible to identify those activities that had an incorrect duration parameter when preparing the scenario. Owing to these outputs, the training could have been optimized so that individual parameter values corresponded to the real training.

\section{Discussion}

The use of SW applications to implement the training for increasing knowledge and skills of the IRS is a commonly used method. SW Practis is a unique SW that serves, in the first place, for support of scenarios and their implementation. In addition, it enables the implementation of a computer-based training, or support (control) the live one. The use of SW in practice has proven to be a suitable method, as it allows a combination of both variants. It also enables live training of less time-consuming activities, while time-consuming activities are performed on the computer. Undoubtedly, the computer-based simulation does not achieve such results as live simulations concerning the realistic nature. However, it makes it possible to save time and financial resources. Compared to the traditional theoretical training, the long-term use of SW in the process of education and preparation of future personnel of the IRS has a positive impact as the SW forces learners to actively use the acquired knowledge. Not only is it recommended to use the SW as a training support tool but it can also be used as a tool for creating scenarios by participants themselves. In this case, however, it is important for the scenario to be subsequently evaluated by an expert who is able to identify any deficiencies. Moreover, the process of using the SW in training brings a new element to learning, which is a game. The topic of further research is to compare the results of traditional training and training based on the SW support in the form of interactive preparation, implementation and evaluation of the training. The case study demonstrates the possibility of using SW Practis for the preparation and implementation of the training; in addition, it can be used to create a model of given events in the form of scenarios. The SW enables visualization of these models for easier understanding and presentation. The results of long-term use proved the creation of the model to be more than beneficial when used together with a traditional lecture format. Besides, compared to the full use of the SW, the implementation of this method is less demanding.

This paper is supported by the Internal Grant Agency at Tomas Bata University in Zlín, projects No. IGA/FLKR/2019/002 and No IGA/FLKŘ/2018/001.

This research was supported by support research program of Tomas Bata University in Zlín (RVO).

\section{References}

1. D. Ryba, Koncepce vzděláváni Hasičského záchranného sboru České republiky, Ministerstvo vnitr, generálni ředitelství hasičského záchranného sboru České republiky Čj. MV-158426-2/PO-PVP-2016, online: www.hzscr.cz/soubor/koncepce-vzdelavani-hzs-pdf.aspx (2016)

2. K. Skalska, Z. Hanuska, M. Dubsky, Integrovaný záchranný system a požární ochrana, Ministerstvo vnitr, generální ředitelství hasičského záchranného sboru České republiky ISBN 978-80-86640-59-4, online: https://www.hzscr.cz/soubor/vzdelavani-v-krizovemrizeni-moduly-modul-i-pdf.aspx (2010)

3. S. Kavan, Podpora dalšiho vzděláváni príslušníku bezpečnostních složek v Jihočeském kraji, CZ.1.07/ 3.2.08/02.0046, online: https://1url.cz/qMBfM (2016)

4. J. Rak, D. Vicar, M. Tomek, B. Svobodova, The simulation of transport accident with the leakage of a hazardous chemical for education in security forces' training. 19th International Scientific Conference on Transport Means, TRANSPORT MEANS, Kaunas University of Technology and Klaipeda, ISSN 1822296X (2015)

5. B. Martinek, Informování veřejnosti a preventivně výchovná činnost, online: http://www.oshpardubice. cz/archiv/oroo/2016_prezentace_preventivne_vychovna_ cinnost.ppt (2016)

6. Katalog typových činností složek IZS, V Ostravě: Sdružení požárního a bezpečnostního inženýrství. (2007)

7. SW Practis, Tsoft a.s. Praha 


\section{SW Terex, Tsoft a.s. Praha}

9. Google maps, online: https://www.google.com/maps 